\title{
Distributions of Cadmium on Electrokinetic Soil Remediation under Condition of Constant Applied Voltage
}

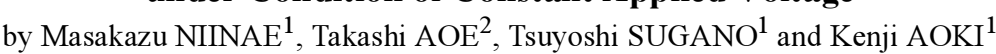

1. Department of Earth Resources Engineering, Faculty of Engineering, Kyoto University, Sakyo-ku, Kyoto 606-8501

2. Graduate Student, Kyoto University

\begin{abstract}
Restoration of contaminated soils to an environmentally acceptable condition is important. Various methods currently used have advantages and limitations in remediating contaminants in soils. In fact, most successful in situ remediation technologies are restricted to soils with relatively high hydraulic conductivity and can not be used for fine-grained deposits. One of the newer techniques in soil remediation is a method based on electrokinetic phenomena in soils. Electrokinetic soil remediation is an effective in situ separation and removal technique used for extraction of heavy metals and some organic compounds from fine-grained soils. The technology uses electricity to affect chemical concentrations and water flow through the pores of soils.

In the present study, the distributions of cadmium in the electrokinetic processing of kaolinite under the condition of constant applied voltage are predicted using a theoretical model that incorporates equilibrium chemistry and the results are compared with experimental findings. The results obtained in this study are summarized as follows:

The distributions of $\mathrm{pH}$ and cadmium simulated by the model show relatively good agreement with experimental results. The steepness of the $\mathrm{pH}$ jump and its influence on the distribution of cadmium are clearly seen Cadmium accumulates in the region of the $\mathrm{pH}$ jump to the cathode. As a consequence of the focussing of cadmium in the region of the $\mathrm{pH}$ jump to the cathode, the decrease in the volume of soil to excavate from the site is advantageous. From experiments, it was also found that the progress of electrokinetic processing of cadmium could be grasped to a certain extent by monitoring the local voltage and the current density.
\end{abstract}

KEY WORDS : Electrokinetics, Contaminated Soils, Soil Remediation, Cadmium

\section{1. 緒}

\section{言}

重金属などの有害污染物質は地下に浸透し, 土壤や地下水を污 染する。地下の環境は地上の環境と異なり污染物質を蓄積しやす く, 数十年前の行為によって土袞や地下水が污染されていること も珍しくない。わが国の土壌污染は鉱山由来の銅, カドミウム, ヒ素などによる農用地污染に始まり, 最近では工場跡地などの再 開発や水質污濁防止法に基づく地下水モニタリングにより, 市街 地の土鎄污染も次第に明らかにされつつある。こうした市街地の 土壌污染では, トリクロロエチレンやテトラクロロエチレンの他 に, カドミウム, 水銀, 七素, 六価クロムなどの重金属が検出さ れることが多い(平田，1996)。

近年, 污染土壌や地下水に対する原位置浄化法の研究・開発が 活発に行われている。原位置浄化法はオンサイトあるいはオフサ イト方式と比べて処理コストが低い, 環境破壊が少ない, 有害物

* 2000 年 4 月 20 日受付 6 月 16 日受理 平成 11 年度資源・素材関倸学協会合 同秋季大会および資源・素材学会平成 12 年度春季大会において一部発表

1. 正会員 工博 京都大学助手 工学研究科資源工学専攻

2. 京都大学院生 工学研究科資源工学専攻

3. 正会員 工博 京都大学助教授 工学研究科資源工学専攻

4. 正会員 工博 京都大学教授 工学研究科資源工学専攻

[ 著者連絡先] FAX 075-753-5428 (京大・資源)

キーワード: 動電学, 污染土壤, 土壤浄化, カドミウム
質による現場従事者への曝露の危険性が小さいなどの利点を有 している。しかし, 実用化あるいは提案されている多くの原位置 浄化技術は, 現在多くの污染サイトで見られる低透水性地盤への 適用が困難であると言われている。

最近, 粘土やシルト層といった微細な土壌粒子で構成された透 水性の低い地盤中の污染物質の処理にも適している原位置浄化 法として, 界面動電現象の利用が検討されるようになってきた (Shapiro et al., 1989 ; Alshawabkeh and Acar, 1992 ; Pamukcu and Wittle, 1992 ; Shapiro and Probstein, 1993 ; Hicks and Tondorf, 1994; Coletta et al., 1997 ; 新苗ら，1998)。この処理方法は地盤中に適当 な間隔で電極を配置し, 直流電流を流すことによりイオン移動 ( 電気泳動) や電気浸透といった界面動電現象を引き起こして污 染物質の濃縮・除去を行う方法である。本手法は先に述べた原位 置浄化法の利点および低透水性地盤に適用できること以外にも， 污染物質を電場でコントロールすることにより, 処理ゾーンの外 への拡散がほとんどないという利点も有する。しかし, 土壌中で 起こるプロセスの複雑さ故に, 污染物質や土壤特性による効果の 違い, 効率的除去のための操作条件について未解明の点が多く, 系統的な研究が強く望まれている。

カドミウムは重金属污染物質として代表的なものであり, 重金 属の移動度および人為的な影響の全体的な評価において, 重金属 
の中で最も優先して浄化対策を講ずる必要がある(F-rstner, 1999)。 そこで本研究ではカドミウムを対象重金属とし, 動電学的手法を 一定の印加電圧の下で適用した場合の土袞中でのカドミウムの挙 動を数值解析および実験の両面から検討した結果について報告する。

\section{2. 数 值 解 析}

\section{$2 \cdot 1$ 物質輸送式}

化学種 $\mathrm{j}$ の土㙵中の単位面積当たりの総流束 $J_{\mathrm{j}}$ は次の NernstPlank の式で示される (Shapiro et al., 1989 ; Alshawabkeh and Acar, 1992)。

$$
J_{\mathrm{j}}=-D_{\mathrm{j}}^{*} \frac{\partial C_{\mathrm{j}}}{\partial x}-C_{\mathrm{j}}\left(u_{\mathrm{j}}^{*}+k_{\mathrm{e}}\right) \frac{\partial E}{\partial x}-C_{\mathrm{j}} k_{\mathrm{h}} \frac{\partial h}{\partial x}
$$

ここで, 添え字 $\mathrm{j}$ は化学種を, $D_{\mathrm{j}}{ }^{*}$ は化学種 $\mathrm{j}$ の多孔質内有効拡散 係数, $C_{\mathrm{j}}$ は濃度, $u_{\mathrm{j}}{ }^{*}$ は多孔質内有効イオン移動度, $E$ は電位差, $k_{\mathrm{e}}$ は電気浸透係数, $h$ は水頭, $k_{\mathrm{h}}$ は透水係数を, また, $x$ は直線 距離を示している。右辺第 1 項は濃度勾配による拡散 (Fick の第 一法則 ), 第 2 項はイオン移動や電気浸透による, 第 3 項は動水 勾配による移動 (Darcy の法則) を表している。なお多孔質内にお ける有効拡散係数と有効イオン移動度は, 無限希釈の自由溶液中 の拡散係数 $D_{\mathrm{j}}$ とイオン移動度 $u_{\mathrm{j}}$ との間に次の関係がある (Alshawabkeh and Acar, 1992)。

$$
\begin{aligned}
D_{\mathrm{j}}^{*} & =D_{\mathrm{j}} \tau n \\
u_{\mathrm{j}}^{*} & =u_{\mathrm{j}} \tau n \\
& =\frac{D_{\mathrm{j}}^{*} z_{\mathrm{j}} F}{R T}
\end{aligned}
$$

ここで $\tau$ は屈曲性を表す要素で, 土壊試料の直線長さを $L_{\mathrm{s}}$, 物質 の移動する経路長を $L_{\mathrm{r}}$ とすると， $\tau=L_{\mathrm{s}}{ }^{2} / L_{\mathrm{r}}{ }^{2}$ で表される。 $n$ は 間隙率, $z_{\mathrm{j}}$ は化学種 $\mathrm{j}$ の電荷数, $F$ は Faraday 定数, $R$ は気体定数 を,また，Tは絶対温度を示している。

化学種 $\mathrm{j}$ の物質収支式は次式で示される。

$$
\frac{\partial n C_{\mathrm{j}}}{\partial t}=-\frac{\partial J_{\mathrm{j}}}{\partial x}+n R_{\mathrm{j}}
$$

ここで $R_{\mathrm{j}}$ は吸着 / 脱着, 沈殿 / 溶解, 酸化 / 還元および液相反応 などによる単位土猿流体体積当たりの水溶性物質 $\mathrm{j}$ の生成割合を 示す。式(1)および式 (4)より次式が導かれる。

$$
\frac{\partial n C_{\mathrm{j}}}{\partial t}=D_{\mathrm{j}}^{*} \frac{\partial^{2} C_{\mathrm{j}}}{\partial x^{2}}+\left[\left(u_{\mathrm{j}}^{*}+k_{\mathrm{e}}\right) \frac{\partial E}{\partial x}+k_{\mathrm{h}} \frac{\partial h}{\partial x}\right] \frac{\partial C_{\mathrm{j}}}{\partial x}+n R_{\mathrm{j}} \cdots \cdots
$$

ただし, 電気浸透係数, 透水係数, 土壤内部の電位勾配および 動水勾配は一定と仮定している。液相での化学反応については別 に化学種ごとの関係式を用いて計算することとし, ここでは $R_{\mathrm{j}}$ に ついて吸着反応のみについて考慮すると, $R_{\mathrm{j}}$ は次式で示される (Alshawabkeh and Acar, 1992)。

$$
\begin{aligned}
R_{\mathrm{j}} & =\frac{\rho}{n} \frac{\partial S_{\mathrm{j}}}{\partial t} \\
& =-\frac{\rho}{n} \frac{\partial S_{\mathrm{j}}}{\partial C_{\mathrm{j}}} \frac{\partial C_{\mathrm{j}}}{\partial t}
\end{aligned}
$$

ここで $\rho$ は土壌の乾燥密度, $S_{\mathrm{j}}$ は乾燥土壌の単位重量当たりの化 学種 $\mathrm{j}$ の吸着量を示している。代表的な吸着等温式には Henry 型, Freundlich 型および Langmuir 型などがあるが, 吸着反応が迅速に 平衡に達寸る場合あるいは物質濃度がそれほど高くない場合には 吸着等温式は直線で近似できることから，ここでは Henry 型の吸 着等温式を仮定することにすると, 式 (6) は次式で示される。

$$
R_{\mathrm{j}}=-\frac{\rho}{n} K \mathrm{~d}_{\mathrm{j}} \frac{\partial C_{\mathrm{j}}}{\partial t}
$$

ここで $K \mathrm{~d}_{\mathrm{j}}$ は分配係数を示す。式 (5)および式 (7) から次式が導か
れる。

$$
\begin{aligned}
& R \mathrm{~d}_{\mathrm{j}} \frac{\partial n C_{\mathrm{j}}}{\partial t}=D_{\mathrm{j}}^{*} \frac{\partial^{2} C_{\mathrm{j}}}{\partial x^{2}}+\left[\left(u_{\mathrm{j}}^{*}+k_{\mathrm{e}}\right) \frac{\partial E}{\partial x}+k_{\mathrm{h}} \frac{\partial h}{\partial x}\right] \frac{\partial C_{\mathrm{j}}}{\partial x} \\
& \text { ここで } R \mathrm{~d}_{\mathrm{j}} \text { は }
\end{aligned}
$$

$$
R \mathrm{~d}_{\mathrm{j}}=1+K \mathrm{~d}_{\mathrm{j}} \frac{\rho}{n}
$$

で示され，遅延係数と呼ばれる。

次に境界条件について考える。境界は電極部分に当たるため, 電極反応に伴う物質の増減を考慮する必要がある。Faraday の法則 より, 物質の総流束 $J_{\mathrm{j}}$ と電流密度 $I$ との間には次の関係がある。

$$
I=F \sum_{\mathrm{j}=1}^{\mathrm{N}} z_{\mathrm{j}} J_{\mathrm{j}}
$$

ここで $\mathrm{N}$ は与えられた化学種の総数を示す。本研究では電極にグ ラファイトのような不活性物質を使用したと仮定し, 水の電気分 解反応のみを考える。Faraday の法則によると電極反応による物質 の生成割合は土袞内の電流通過量と等価であること, また, 本研 究では水の電気分解反応のみとしているので, 陽極では水素イオ ンの発生のみを, 陰極では水酸化物イオンの発生のみを考える。 この場合, 陽極および陰極での境界条件式は各々次式で示される。

$$
\begin{aligned}
& -D_{\mathrm{H}^{+}}^{*} \frac{\partial C_{\mathrm{H}^{+}}}{\partial x}-\left[\left(u_{\mathrm{H}^{+}}^{*}+k_{\mathrm{e}}\right) \frac{\partial E}{\partial x}+k_{\mathrm{h}} \frac{\partial h}{\partial x}\right] C_{\mathrm{H}^{+}} \|_{x=0}=\frac{I}{F} \quad \cdots \cdots \\
& -D_{\mathrm{OH}^{-}}^{*} \frac{\partial C_{\mathrm{OH}^{-}}}{\partial x}-\left[\left(u_{\mathrm{OH}^{-}}^{*}+k_{\mathrm{e}}\right) \frac{\partial E}{\partial x}+k_{\mathrm{h}} \frac{\partial h}{\partial x}\right] C_{\mathrm{OH}^{-}} \|_{x=L}=-\frac{I}{F}
\end{aligned}
$$

ただし, 陽極では水素イオンのみが, 陰極では水酸化物イオンの みが計算されているが，一方のイオン濃度については水のイオン 積から計算されることになる。他の化学種については電極反応に 関与しないものとし，境界条件式は次式で示される。

$$
-D_{\mathrm{i}}^{*} \frac{\partial C_{\mathrm{i}}}{\partial x}-\left[\left(u_{\mathrm{i}}^{*}+k_{\mathrm{e}}\right) \frac{\partial E}{\partial x}+k_{\mathrm{h}} \frac{\partial h}{\partial x}\right] C_{\mathrm{i}}=0
$$

上記境界条件の下で式 (8) を有限差分法を用いて物質移動の数 值計算を行った。まず, 式 (8) の左辺に対して前進差分を, 右辺 に対して中心差分を適用して近似し差分方程式を導いた。これは 移流・拡散方程式に対する最も基本的な手法である。しかしこの 場合, 式 (8) の右辺第 2 項の移流速度に関する項 $\left(\left(u_{\mathrm{j}}^{*}+k_{\mathrm{e}}\right) \partial E / \partial x\right.$ $\left.+k_{\mathrm{h}} \partial h / \partial x\right)$ が大きく変化した場合に解の安定性が保たれなく なった。そこで式 (8) の右辺第 2 項に対して中心差分ではなく, 次 に示すような風上差分を用いることにした。

$$
\begin{aligned}
& n R \mathrm{~d}_{\mathrm{j}} \frac{C_{\mathrm{j}, \mathrm{i}}^{\mathrm{k}+1}-C_{\mathrm{j}, \mathrm{i}}^{\mathrm{k}}}{\Delta t}=D_{\mathrm{j}}^{*} \frac{C_{\mathrm{j}, \mathrm{i}+1}^{\mathrm{k}}-2 C_{\mathrm{j}, \mathrm{i}}^{\mathrm{k}}+C_{\mathrm{j}, \mathrm{i}-1}^{\mathrm{k}}}{(\Delta x)^{2}}+ \\
& {\left[\left(u_{\mathrm{j}}^{*}+k_{\mathrm{e}}\right) \frac{\partial E}{\partial x}+k_{\mathrm{h}} \frac{\partial h}{\partial x}\right]\left[\begin{array}{l}
\frac{C_{\mathrm{j}, \mathrm{i}+1}^{\mathrm{k}}-C_{\mathrm{j}, \mathrm{i}}^{\mathrm{k}}}{\Delta x},\left(u_{\mathrm{j}}^{*}+k_{\mathrm{e}}\right) \frac{\partial E}{\partial x}+k_{\mathrm{h}} \frac{\partial h}{\partial x}>0 \\
\frac{C_{\mathrm{j}, \mathrm{i}}^{\mathrm{k}}-C_{\mathrm{j}, \mathrm{i}-1}^{\mathrm{k}}}{\Delta x},\left(u_{\mathrm{j}}^{*}+k_{\mathrm{e}}\right) \frac{\partial E}{\partial x}+k_{\mathrm{h}} \frac{\partial h}{\partial x} \leq 0
\end{array}\right.}
\end{aligned}
$$

ここで $\mathrm{j}$ は化学種, $\mathrm{i}(=1,2, \cdots \cdot \mathrm{N})$ は節点番号, $k$ は時間を示 している。この場合, 計算精度は 2 次ではなく 1 次となる。中心 差分の場合, 計算精度は 2 次であるが, Courant 条件を満たしてい ても解が振動し, 数值安定性を保つことが困難であった。風上差 分の場合, 計算精度は中心差分に比べて落ちるが解は安定する。 ここで,

$$
\begin{gathered}
\alpha=\frac{D_{\mathrm{j}}^{*}}{n R \mathrm{~d}_{\mathrm{j}}} \frac{\Delta t}{(\Delta x)^{2}} \quad \ldots \ldots \ldots \ldots \ldots \ldots . . . . . . \\
\gamma=\frac{\left(u_{\mathrm{j}}^{*}+k_{\mathrm{e}}\right) \frac{\partial E}{\partial x}+k_{\mathrm{h}} \frac{\partial h}{\partial x}}{n R \mathrm{~d}_{\mathrm{j}}} \frac{\Delta t}{\Delta x}
\end{gathered}
$$


とすると, 式 (14) は次式で表すことができる。

$$
\begin{aligned}
& C_{\mathrm{j}, \mathrm{i}}^{\mathrm{k}+1} \\
& =\left\{\begin{array}{l}
(\alpha+\gamma) C_{\mathrm{j}, \mathrm{i}+1}^{\mathrm{k}}-(2 \alpha+\gamma-1) C_{\mathrm{j}, \mathrm{i}}^{\mathrm{k}}+\alpha C_{\mathrm{j}, \mathrm{i}-1}^{\mathrm{k}},\left(u_{\mathrm{j}}^{*}+k_{\mathrm{e}}\right) \frac{\partial E}{\partial x}+k_{\mathrm{h}} \frac{\partial h}{\partial x}>0 \\
\alpha C_{\mathrm{j}, \mathrm{i}+1}^{\mathrm{k}}-(2 \alpha-\gamma-1) C_{\mathrm{j}, \mathrm{i}}^{\mathrm{k}}+(\alpha-\gamma) C_{\mathrm{j}, \mathrm{i}-1}^{\mathrm{k}},\left(u_{\mathrm{j}}^{*}+k_{\mathrm{e}}\right) \frac{\partial E}{\partial x}+k_{\mathrm{h}} \frac{\partial h}{\partial x} \leq 0
\end{array}\right.
\end{aligned}
$$

式 (17) を用いることにより, 化学種 $\mathrm{j}$ に対して次の時間ステップ における濃度計算を行った。ただし, 本研究では $\partial h / \partial x=0$ とし, 動水勾配による移流の項は無視している。

本研究では対象重金属としてカドミウムを選び，その場合に考 えられる化学反応として以下に示す反応を考慮した。

$$
\begin{aligned}
& \mathrm{H}^{+}+\mathrm{OH}^{-}=\mathrm{H}_{2} \mathrm{O} \\
& \mathrm{Cd}^{2+}+2 \mathrm{OH}^{-}=\mathrm{Cd}(\mathrm{OH})_{2} \downarrow \\
& \mathrm{Cd}^{2+}+3 \mathrm{OH}^{-}=\mathrm{Cd}(\mathrm{OH})_{3}^{-}
\end{aligned}
$$

上記反応は移流, 拡散およびイオン移動などによる物質移動速 度と比べて迅速に起こると仮定し, 各化学種の移動が終わる微小 時間後に以下に示す化学平衡条件を満足するように濃度調整およ び物質濃度が決定された。

$\left[\mathrm{H}^{+}\right]\left[\mathrm{OH}^{-}\right]=K_{\mathrm{w}}$

$\left[\mathrm{Cd}^{2+}\right]\left[\mathrm{OH}^{-}\right]^{2}=K_{\mathrm{s}}$

$$
\frac{\left[\mathrm{Cd}(\mathrm{OH})_{3}^{-}\right]}{\left[\mathrm{Cd}^{2+}\right]\left[\mathrm{OH}^{-}\right]^{3}}=\beta_{3}
$$

ここで $K_{\mathrm{w}}$ は水のイオン積, $K_{\mathrm{s}}$ は溶解度積および $\beta_{3}$ は安定度定数 を示している。濃度の調整は各々の化学種について濃度変化 $\Delta C_{\mathrm{j}}$ を求めることによって行う。ただし, 式 (22) の $\mathrm{Cd}(\mathrm{OH})_{2}$ の生成反 応については, 左辺の值が溶解度積の值を超えた場合の夕計算し た。以上式 (21) から式(23) を考慮し, 一度に連立させることによ り濃度変化 $\Delta C_{\mathrm{j}}$ を求め, カドミウムとの反応に伴う水酸化物イオ ンの消費を考慮して数值解析を行った。ただし, この場合高次の 連立方程式を解く必要があり, 本研究では減速ニュートン法を用 いた。

\begin{tabular}{|c|c|c|}
\hline Porosity [\%] & $n$ & 50.0 \\
\hline Tortuosity factor & $\tau$ & 0.35 \\
\hline Applied voltage $[\mathrm{V}]$ & $\Delta E$ & 20.0 \\
\hline Length of porous media $[\mathrm{cm}]$ & $L$ & 20.0 \\
\hline Retardation factor & $R \mathrm{~d}$ & 10.0 \\
\hline Initial $\mathrm{pH}$ & & 5.0 \\
\hline Coefficient of electroosmotic permeability $\left[\mathrm{cm}^{2} / \mathrm{V} \cdot \mathrm{s}\right]$ & $k_{\mathrm{e}}$ & $\left.3.60 \times 10^{-5} 1\right)$ \\
\hline Initial $\mathrm{Cd}$ concentration $\left[\mathrm{mol} / \mathrm{dm}^{3}\right]$ & & $1.00 \times 10^{-3}$ \\
\hline Diffusion coefficient of $\mathrm{H}^{+}\left[\mathrm{cm}^{2} / \mathrm{s}\right]$ & $D_{\mathrm{H}^{+}}$ & $9.31 \times 10^{-522}$ \\
\hline Diffusion coefficient of $\mathrm{OH}^{-}\left[\mathrm{cm}^{2} / \mathrm{s}\right]$ & $\mathrm{DoH}^{-}$ & $5.30 \times 10^{-53)}$ \\
\hline Diffusion coefficient of $\mathrm{Cd}^{2+}\left[\mathrm{cm}^{2} / \mathrm{s}\right]$ & $D \mathrm{Cd}^{2+}$ & $7.19 \times 10^{-6} *$ \\
\hline Diffusion coefficient of $\mathrm{Cd}(\mathrm{OH})_{3} \cdot\left[\mathrm{cm}^{2} / \mathrm{s}\right]$ & $D_{\mathrm{Cd}(\mathrm{OH})_{3}}{ }^{-}$ & $7.19 \times 10^{-6}$ \\
\hline Ionic mobility of $\mathrm{H}^{+}\left[\mathrm{cm}^{2} / \mathrm{V} \cdot \mathrm{s}\right]$ & $u_{\mathrm{H}^{+}}^{+}$ & $\left.3.62 \times 10^{-3} 2\right)$ \\
\hline Ionic mobility of $\mathrm{OH}^{-}\left[\mathrm{cm}^{2} / \mathrm{V} \cdot \mathrm{s}\right]$ & $\mathrm{oH}^{-}$ & $2.06 \times 10^{-33)}$ \\
\hline Ionic mobility of $\mathrm{Cd}^{2+}\left[\mathrm{cm}^{2} / \mathrm{V} \cdot \mathrm{s}\right]$ & $u \mathrm{Cd}^{2+}$ & $\left.5.60 \times 10^{-4} 4\right)$ \\
\hline Ionic mobility of $\mathrm{Cd}(\mathrm{OH})_{3} \cdot\left[\mathrm{cm}^{2} / \mathrm{V} \cdot \mathrm{s}\right]$ & $u_{\mathrm{Cd}(\mathrm{OH})_{3}}{ }^{-}$ & $2.80 \times 10^{-4}$ \\
\hline Ion product $\left[\left(\mathrm{mol} / \mathrm{dm}^{3}\right)^{2}\right]$ & $K_{\mathrm{w}}$ & $1.00 \times 10^{-14}$ \\
\hline Solubility product of $\mathrm{Cd}(\mathrm{OH})_{2}\left[\left(\mathrm{~mol} / \mathrm{dm}^{3}\right)^{3}\right]$ & $K_{\mathrm{s}}$ & $2.51 \times 10^{-145}$ \\
\hline Stability constant of $\mathrm{Cd}(\mathrm{OH})_{3} \cdot\left[\left(\mathrm{mol} / \mathrm{dm}^{3}\right)^{-3}\right]$ & $\beta_{3}$ & $2.00 \times 10^{105)}$ \\
\hline
\end{tabular}

\section{$2 \cdot 2$ 数值解析結果および考察}

$2 \cdot 2 \cdot 1 \mathrm{pH}$ 分布 本研究において解析に用いたパラメー タを Table 1 に示す。土壤試料の長さおよび印加電圧は後で示す 実験と同条件に設定した。また, 間隙率 $n$ および屈曲性を表す要

Table 1 Model parameters

1) Segall and Bruell, 1992 ; 2) Alshawabkeh and Acar, 1992 ; 3) Atkins, 1993 ; 4）日本化学会, 1958 ; 5) Ringbom, $1965 ; *$ Einstein の関係式より算出
素 $\tau$ は，粘土質土壌の代表的な值を用いた。遅延係数 $R_{\mathrm{d}}$ に対する 正確な值が無いため, 土㙵とまったく反応しない場合は $R_{\mathrm{d}}=1$ で あること, また, 最大でも $R_{\mathrm{d}}=20$ 程度の值が用いられていること から, 本研究ではその中間值として $R_{\mathrm{d}}=10$ を用いた。カドミウム の液相内における反応は, 先に示したように $\mathrm{Cd}(\mathrm{OH})_{2}$ の沈殿生成 反応および $\mathrm{Cd}(\mathrm{OH})_{3}^{-}$の錯形成反応を考慮した。なお $\mathrm{Cd}(\mathrm{OH})_{3}^{-}$の 拡散係数およびイオン移動度のデータがないことから, 拡散係数 については $\mathrm{Cd}^{2+}$ と同じに, イオン移動度については $\mathrm{Cd}^{2+}$ の半分 と仮定した。

土壌内における $\mathrm{pH}$ 分布の経時变化を Figs. 1 および 2 に示す。 どちらも同じ図であるが Fig. 2 は $\mathrm{pH}$ が急激に変化する領域を拡大 して示している。水の電気分解反応の結果, 陽極から $\mathrm{H}^{+}$が, 陰 極から $\mathrm{OH}^{-}$が発生し, 各々が陰極および陽極方向へ進行し, 両者 の衝突により $\mathrm{pH}$ が急激に变化する領域が存在することが分かる。

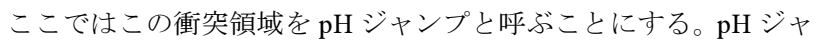
ンプは $\mathrm{H}^{+}$のイオン移動度が $\mathrm{OH}^{-}$のイオン移動度より大きいため,

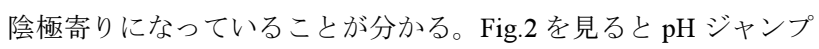
は24時間から 48 時間にかけて一度陰極方向に移動し, その後徐々

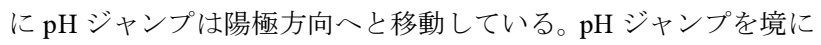
酸性領域と塩基性領域にはっきり分かれることが分かった。

$2 \cdot 2 \cdot 2$ カドミウム濃度の経時変化 Fig.3および 4 に土㗒 内のカドミウム濃度の経時変化を示す。どちらも同じ図であるが 縦軸のスケールを変えて示している。カドミウムが $\mathrm{pH}$ ジャンプ から陰極側にかけて蓄積していることが分かる。また, カドミウ ムが蓄積している部分をさらに拡大して検討した結果, 先に示し

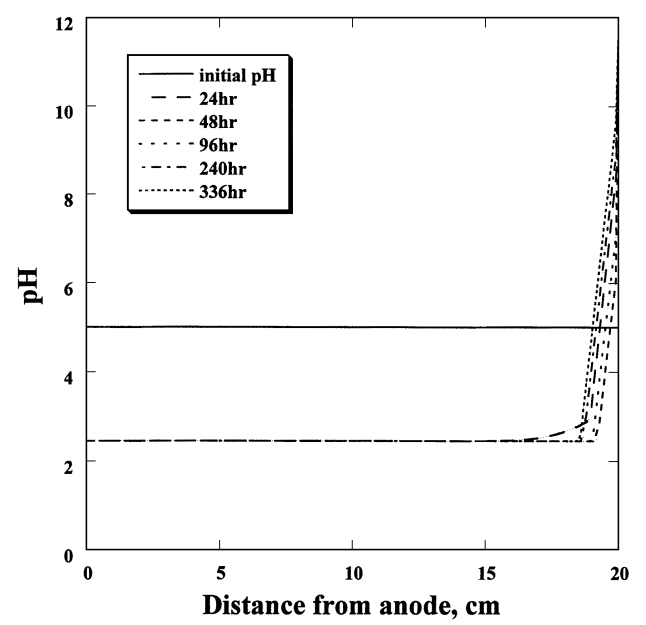

Fig.1 Calculated distributions of $\mathrm{pH}$.

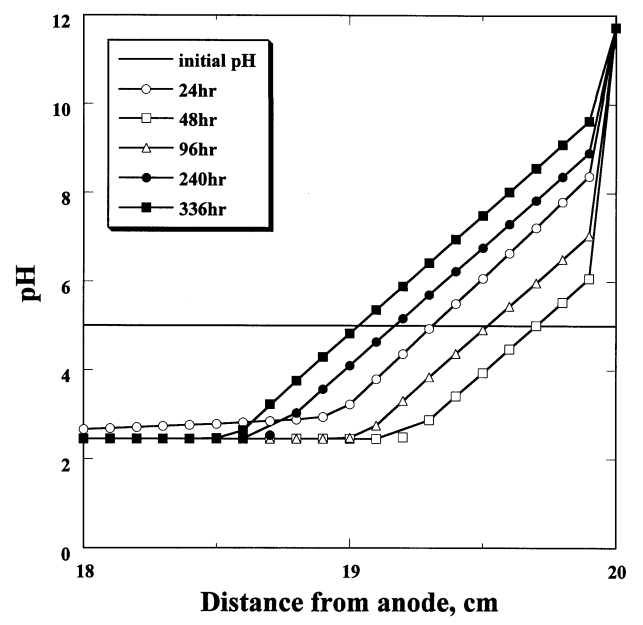

Fig.2 Calculated distributions of $\mathrm{pH}$. 


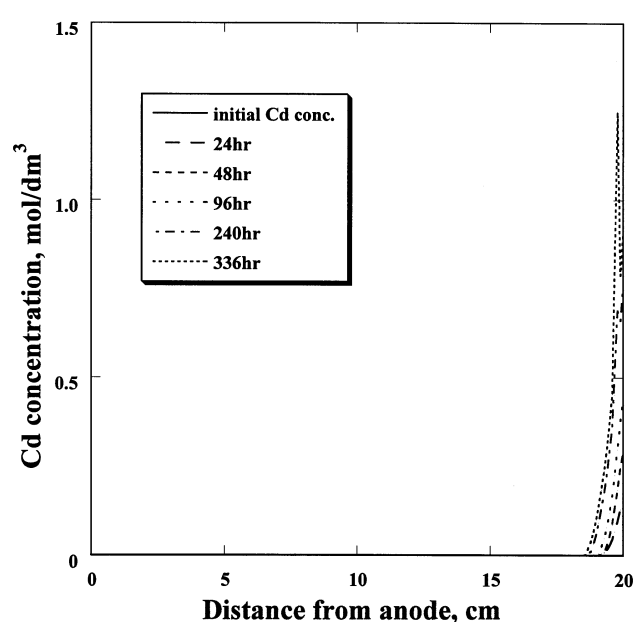

Fig.3 Calculated distributions of $\mathrm{Cd}$ concentration.

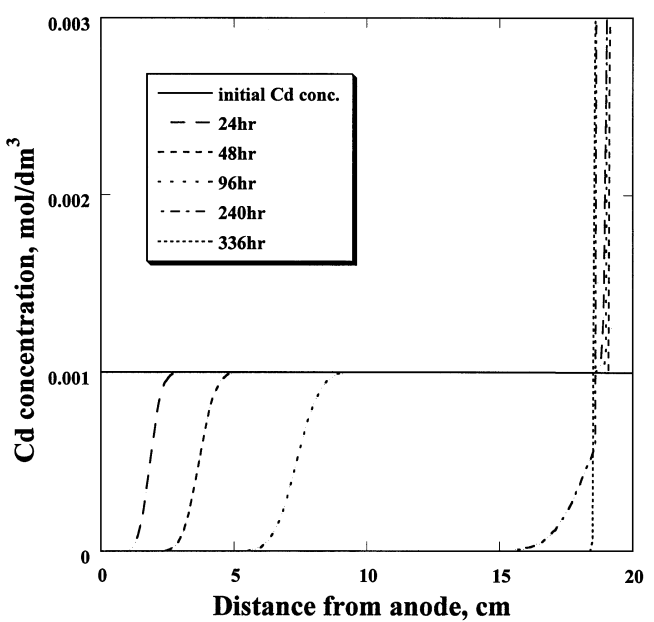

Fig.4 Calculated distributions of Cd concentration.

た $\mathrm{pH}$ 分布の経時変化に対応してカドミウムが蓄積していること が分かった。また, Fig.4 を見るとカドミウムは酸性化された領域

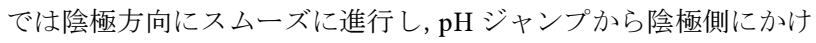
て滞留していることが分かる。酸性化された領域ではカドミウム はほぼ完全に除去されている。酸性化された領域ではカドミウム は $\mathrm{Cd}^{2+}$ として存在し, イオン移動と電気浸透による移流が主な駆 動力となって陰極方向に移動することになる。 $\mathrm{pH}$ の高い領域では $\mathrm{Cd}(\mathrm{OH})_{2}$ として沈殿する。ただし $\mathrm{pH}$ がさらに高くなると $\mathrm{Cd}(\mathrm{OH})_{3}^{-}$

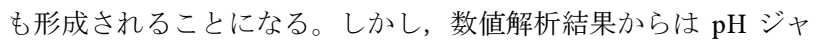
ンプより陰極側での $\mathrm{Cd}(\mathrm{OH})_{3}^{-}$の陽極方向への移動は顕著には見ら れなかった。先に示した $\mathrm{pH}$ 分布の経時変化において，24 時間か ら 48 時間にかけて $\mathrm{pH}$ ジャンプが一度陰極方向に移動したのは, 陰極近傍へのカドミウムの移動と主に $\mathrm{Cd}(\mathrm{OH})_{2}$ の生成による $\mathrm{OH}^{-}$ の消費が大きく影響したものと考えられる。その後大部分のカド ミウムが $\mathrm{Cd}(\mathrm{OH})_{2}$ として固定されたため, 陰極で発生する $\mathrm{OH}^{-}$の 消費が減少し, $\mathrm{pH}$ ジャンプをわずかであるが徐々に陽極方向に移 動させたものと考えられる。

このように土壌に通電を行うことにより $\mathrm{pH}$ ジャンプから陰極 側にかけての狭い領域にカドミウムを濃縮することは可能であ り, その領域のみを掘削・除去することにより完全な浄化を達成 できるものと考えられる。

\section{3. 実験}

$3 \cdot 1$ 実験方法および試料

実験に用いた装置の概略図を Fig.5 に示す。実験に使用した土

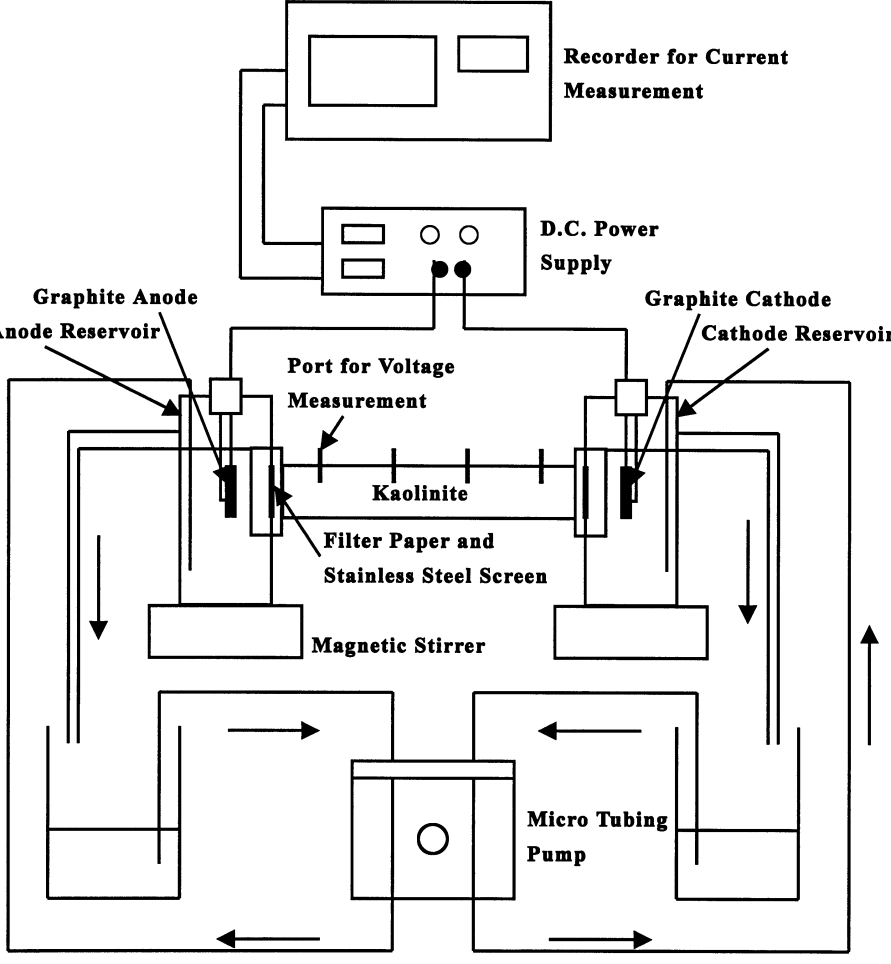

Fig.5 Schematic diagram of experimental apparatus

袞試料は $1: 1$ 型粘土鉱物であるカオリナイト (South Carolina, USA) である。硝酸カドミウム・4 水和物 $\left(\mathrm{Cd}\left(\mathrm{NO}_{3}\right)_{2} \cdot 4 \mathrm{H}_{2} \mathrm{O}\right.$, ナカライ テスク ) および硝酸ナトリウム $\left(\mathrm{NaNO}_{3}\right.$, ナカライテスク $)$ を純水 に溶解し, カドミウム濃度 $8.9 \times 10^{-4} \mathrm{~mol} / \mathrm{dm}^{3}$ および硝酸ナト リウム濃度 $1.0 \times 10^{-2} \mathrm{~mol} / \mathrm{dm}^{3}$ の溶液を調整し, この溶液とカ オリナイトを 24 時間攪拌混合した後, 遠心分離することによりカ ドミウムで污染した飽和土壌試料を作成した。この飽和土猿試料 を長さ $20 \mathrm{~cm}$, 直径 $2 \mathrm{~cm}$ の透明塩ビ製円筒カラムに充填し, その 両端をグラファイト電極 ( 直径 $2 \mathrm{~cm}$ 円盤形) を保持した電極槽に 接続した。円筒カラムと電極槽の間は孔径 $1.0 \mu \mathrm{m}$ のフィルタペー パーとステンレス製金網で仕切られている。フィルタペーパーは 土畩試料が電極槽に漏出するのを防ぐためであり，ステンレス製 金網はフィルタペーパーを支持すると同時に参照電極の役割を果 たす。円筒カラムには土壌内部の電位を測定するための微小な孔 を等間隔に 4 か所開けている。

電極液には $1.0 \times 10^{-2} \mathrm{~mol} / \mathrm{dm}^{3}$ の硝酸ナトリウム溶液を使用 した。電極液はマグネチックスターラーで常に攪拌した。また液 圧差による移流の発生を防ぐために電極液の高さが両電極槽で一 定になるように同じ高さでオーバーフローするようにした。オー バーフローした電極液はマイクロチュービングポンプで再び電極 槽に戻すようにした。

定電圧直流電源を用いて両グラファイト電極間の電圧を $20 \mathrm{~V}$ 一 定として実験を行った。実験は設定した印加電圧のもとで 336 時 間 (2 週間) 通電を行った。通電中は両電極槽内の $\mathrm{pH}$ 変化を監視 し，また土袞内部の電位変化についても円筒カラム両端に設置し たステンレス製金網と円筒カラムに設けた 4 か所の孔に電極を挿 入することにより, 計 $6 つ の$ 電極を用いて測定した。また電源側 にデータレコーダを取り付け電流值の変化を監視した。通電終了 後, 円筒カラムを $2 \mathrm{~cm}$ ごとに切断し, 10 のセクションに分割し た。各々のセクションについて $\mathrm{pH}$ 電極 (東亜電波工業 (株) 製つ きさし用 $\mathrm{pH}$ 複合電極 $\mathrm{GST}-5724 \mathrm{C})$ を用いて $\mathrm{pH}$ を測定し, 最終 的な土壤内の $\mathrm{pH}$ 分布を求めた。なお初期土壌 $\mathrm{pH}$ は 4.20 であっ 
た。その後，各セクションの土袞試料および初期土袞試料を 110 으 24 時間乾燥させた後, $1 \mathrm{~g}$ ずつ分取し, $1.4 \mathrm{~mol} / \mathrm{dm}^{3}$ の硝酸 溶液でカドミウムを抽出した。遠心分離を行った後, 上澄夕液の カドミウム濃度を原子吸光分析装置 (日本ジャーレルアッシュ (株) 製 $\mathrm{AA}-855$ 型）を用いて定量した。

\section{$3 \cdot 2$ 実験結果および考察}

$3 \cdot 2 \cdot 1$ 電極槽の $\mathrm{pH}$ 変化 両電極槽における $\mathrm{pH}$ の経時変 化を Fig.6 に示す。陽極槽の $\mathrm{pH}$ は実験開始後 12 時間程度で大き く減少し, その後 $\mathrm{pH} 2.3$ 程度でほとんど一定となった。一方, 陰 極槽の $\mathrm{pH}$ は 12 時間で $\mathrm{pH} 11$ 程度まで大きく増加し, その後逆に $\mathrm{pH}$ が減少し, 実験開始 120 時間以後は約 $\mathrm{pH} 9.3$ で安定した。

$3 \cdot 2 \cdot 2$ 土壤内の $\mathrm{pH}$ 分布 通電終了 (336 時間) 後に測定 した土㙵内部の $\mathrm{pH}$ 分布を Fig.7 に示す。ただし, $2 \mathrm{~cm}$ ごとに分 割した各セクションの中心位置の $\mathrm{pH}$ 值として示している。先に 示した数值解析で予測されたように酸性領域が陰極方向へ進行 し, 陰極槽の手前で塩基性領域と衝突し, $\mathrm{pH}$ ジャンプを形成して いることが分かる。陰極近傍での $\mathrm{pH}$ 上昇がそれほど大きくなかっ たが，それでも初期土壌 $\mathrm{pH}(4.20)$ を大きく上回っており, 酸性領 域が塩基性領域を土壌系外に洗い流寸までには至っていない。

$3 \cdot 2 \cdot 3$ 土㙵内のカドミウム濃度分布 通電終了(336時間) 後に測定した土畩の各セクションごとのカドミウムの濃度分布を Fig.8 に示す。土壌内の $\mathrm{pH}$ 分布と同様に各セクションでの中心位 置での值としている。ただし, 測定したカドミウム濃度と土䁃の 初期カドミウム濃度の比で示している。先に示した数值解析結果 と同様に, 酸性化された領域においてはほぼ完全にカドミウムが

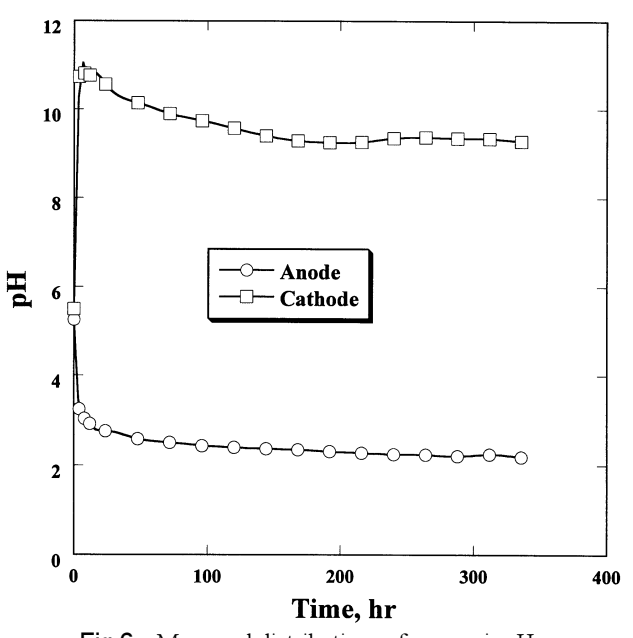

Fig.6 Measured distributions of reservoir $\mathrm{pH}$.

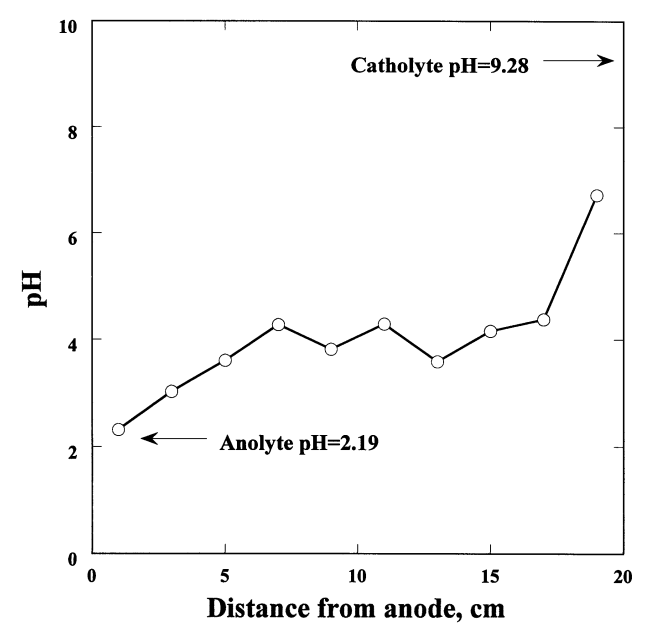

Fig.7 Measured distribution of $\mathrm{pH}$ at $336 \mathrm{hr}$
除去されており, $\mathrm{pH}$ ジャンプから陰極側にかけてカドミウムが蓄 積していることが分かる。また, 陽極槽および陰極槽からはカド ミウムが全く検出されず，カドミウムはすべてこの部分に濃縮さ れていることが分かった。実験からも土袞に通電することにより 陰極近傍にカドミウムを濃縮できることが確かめられた。陰極近 傍の測定 $\mathrm{pH}$ が約 6.8 で陰極槽の $\mathrm{pH}$ が 9.28 であることから, カド ミウムは濃縮部分において $\mathrm{Cd}(\mathrm{OH})_{2}$ として沈殿したものと考えら れる。

$3 \cdot 2 \cdot 4$ 電流密度変化 Faradayの法則によると電極反応に よる物質の生成割合は土壤内の電流通過量と等価であることか ら, 電流 ( 電流密度) 值が大きくなればそれだけ両電極槽におけ る $\mathrm{H}^{+}$および $\mathrm{OH}^{-}$の発生量は増加する。そこで電流密度の経時変 化を Fig. 9 に示す。通電開始後数時間は比較的電流密度は高く 0.6 〜 $0.67 \mathrm{~mA} / \mathrm{cm}^{2}$ の值を示し, 大量 $\mathrm{H}^{+}$および $\mathrm{OH}^{-}$が発生したも のと考えられる。しかし, 電流密度は時間の経過とともに減少し

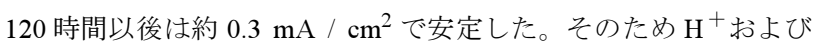
$\mathrm{OH}^{-}$の発生量も同様に低下し, 120 時間以後はほぼ一定になった ものと考えられ，これは先に示した両電極槽の $\mathrm{pH}$ の経時変化と も一致する。また, Fig.7で示した土壌内の $\mathrm{pH}$ 分布において, 陽 極側から $\mathrm{pH}$ ジャンプにかけての領域の $\mathrm{pH}$ の值が数值解析から予 測されたほどには低下しなかった。この原因も, 電流密度の減少 により $\mathrm{H}^{+}$の発生量が抑制された結果, 理想化された数值解析結 果ほどには pH が下がらなかったものと考えられる。電流密度が 安定した 120 時間程度でほぼすべてのカドミウムが陰極近傍に移 動し,この部分に蓄積したと考えられる。

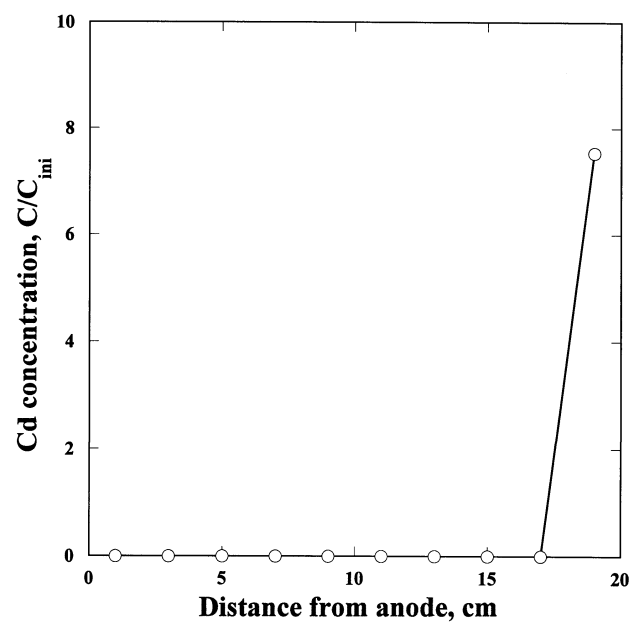

Fig.8 Measured distribution of Cd concentration at $336 \mathrm{hr}$.

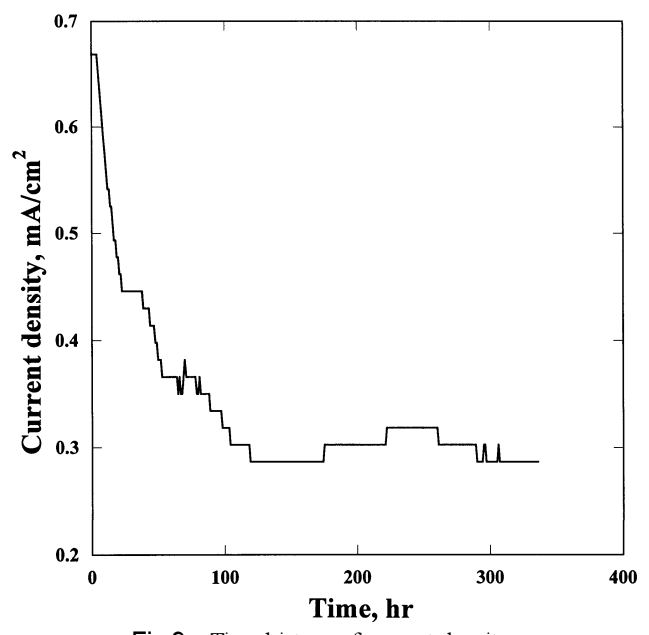

Fig.9 Time history of current density 


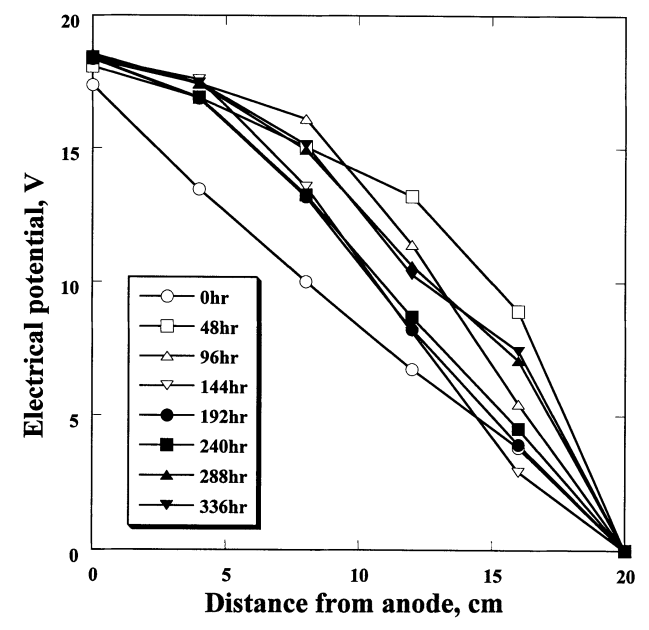

Fig.10 Measured distributions of electrical potential.

$3 \cdot 2 \cdot 5$ 土壌内の電位変化 Fig.10 に土壌内部の電位の経 時変化を示す。土猿内部の電位分布は陽極近傍で電位勾配が小さ く, 陰極方向に向かうにつれて電位勾配が大きくなる傾向を示し た。陰極近傍ではカドミウムは $\mathrm{Cd}(\mathrm{OH})_{2}$ を生成するため, 陽極近 傍に比べて相対的に導電率が減少するため電位勾配が大きくなっ たものと考えられる。また $\mathrm{H}^{+}$と $\mathrm{OH}^{-}$のみで導電率を考えると, 水のイオン積から pH7 のときに最小のイオン濃度 $\left(2.0 \times 10^{-7} \mathrm{~mol}\right.$ $\left./ \mathrm{dm}^{3}\right)$ になることが分かる。したがって, 陰極近傍の $\mathrm{pH}$ ジャン プで pH7 となる位置が存在することになり, その結果陰極近傍で 導電率が減少することになる。一方, カドミウムの導電率への寄 与を考えると, 酸性化された領域では $\mathrm{Cd}^{2+}$ として存在するため, 導電性が良くなる一方で電位勾配は小さくなる。このように電流 密度および電位分布の経時変化を監視することにより土壌内の浄 化プロセスの進行具合をある程度把握できると考えられる。

\section{4. 結}

\section{言}

カドミウムで污染された土㙵を対象に, 一定の印加電圧の下で 直流電流を流した場合にカドミウムなどの化学種がどのような挙 動を示すか数值解析および実験の両面から検討し, 以下のような 結果が得られた。

1）陽極で発生した酸と陰極で発生した塩基が陰極手前で衝突 し, $\mathrm{pH}$ ジャンプを形成する。

2）カドミウムは酸の進出により酸性化された領域においてほ ぼ完全に除去されるが, $\mathrm{pH}$ ジャンプから陰極側にかけて滞留・濃 縮される。しかし, カドミウムが濃縮した領域のみを掘削・除去 することにより対象領域の浄化を行うことが可能である。

3）電流密度変化および土㙵内部の電位変化を監視することに より，浄化プロセスの進行具合をある程度把握できる。

4) 土袞内の $\mathrm{pH}$ 分布およびカドミウム濃度分布に対する数值解 析結果と実験結果に比較的良好な一致がみられた。

\section{引用文献}

Alshawabkeh, A. N. and Acar, Y. (1992) : J. Environ. Sci. Health, Part A, Vol. 27, p. 1835 1861

Atkins, P. W. 著, 千原秀明・中村亘男 訳 (1993)：アトキンス物理化学 (下), 東京化 学同人 (東京), データ表, p. 10

Coletta, T. F., Bruell, C. J., Ryan, D. K. and Inyang, H. (1997) : J. Environ. Eng., Vol. 123, p. $1227-1233$

F rstner, U. 著, 桶口壮太郎・唐土明浩・森 孝信・龍 吉生 訳 (1999) : 地球環境保 全ガイドブックー生産プロセスにおけるグリーンテクノロジー,(株) エヌ・ ティー・エス (東京), p. 263

Hicks, R. E. and Tondorf. S. (1994) : Environ. Sci. Technol., Vol. 28, p. $2203-2210$

平田健正 編 (1996)：土䁃 - 地下水污染と対策，日本環境測定分析協会，p. 10

日本化学会 編 (1958): 化学便覧, 丸善 (東京), p. 862

新苗正和・青江 崇・岸 涉・菅野 強 (1998): 資源と素材, Vol. 114, p. $801-806$ Pamukcu, S. and Wittle, J. K. (1992) : Environ. Prog., Vol. 11, p. $241-250$

Ringbom, A. 著, 田中信行・杉 睛子 共訳 (1965)：錯形成反応一分析化学における 応用一, 産業図書 (東京), p. 272, p. 319

Segall, B. A. and Bruell, C. J.(1992) : J. Environ. Eng., Vol. 118, p. $84-100$

Shapiro, A. P., Renaud, P. C. and Probstein, R. F. (1989): Phisicochem. Hydrodyn., Vol. 11, p. $785-802$

Shapiro, A. P. and Probstein, R. F. (1993) : Environ. Sci. Technol., Vol. 27, p. $283-291$ 